\title{
Synthesis of New -1,3,4-Thiadiazoles Substituted with Oxazepine and Benzoxazepine Moieties
}

\author{
FAEZ ABDUL-HUSSEIN ALRAMMAHI ${ }^{1}$, QASIM MEHDI ISMAEL ${ }^{1}$ and \\ ZEID HASSAN ABOOD ${ }^{2 *}$ \\ 'Department of Chemistry, Faculty of Education for Girls , University of Kufa, Najaf, Iraq. \\ ${ }^{2}$ Department of Chemistry, College of Science, University of Kerbala, kerbala, Iraq. \\ ${ }^{*}$ Corresponding author E-mail: zeid.ab2013@yahoo.com \\ http://dx.doi.org/10.13005/ojc/330536
}

(Received: May 02, 2017; Accepted: June 06, 2017)

\begin{abstract}
2-amino-5-mercapto-1,3,4-thiadiazole 1 was introduced in condensation reaction with terephthaldehyde to yield bis-imine derivative 2. Compound 1 was also converted to the corresponding diazonium salt which was introduced in coupling reactions with alkaline solution of 2-hydroxybenzaldehyde and 4-hydroxybenzaldehyde as coupling reagents to give azo derivatives $4 \mathrm{a}$ and $4 \mathrm{~b}$ containing aldehyde group, respectively. The resulting aldehydes $4 \mathrm{a}$ and $4 \mathrm{~b}$ were then introduced in condensation reactions with 2-amino-5-mercapto-1,3,4-thiadiazole 1 to obtain the imines $5 \mathrm{a}$ and $5 \mathrm{~b}$ respectively. The resulting imines $2,5 \mathrm{a}$ and $5 \mathrm{~b}$ were treated with both maleic and phthalic anhydrides, respectively, under $(2+5)$ cycloaddition conditions afforded eight new bis-1,3,4-thiadiazoles substituted with 1,3-oxazepine and 1,3-benzoxazepine moieties (3a, 3b) and $(6 a-d)$ respectively. The new synthesized thiadiazoles have some biological, pharmaceutical and medicinal applications.
\end{abstract}

Keywords: 1,3,4-thiadiazoles, 2-amino-5-mercapto-1,3,4-thiadiazole, imines, 1,3-oxazepines, 1,3-benzoxazepines, heterocyclic, bis-diazonium, terephthaldehyde.

\section{INTRODUCTION}

Thiadiazoles are clear to yellowish liquids which are soluble in alcohol, ether and slightly soluble in water; they are starting material for numerous chemical compounds including sulphur drugs $^{1}$. Thiadiazoles are easily metabolized by biochemical reactions and they are noncarcinogenic in nature ${ }^{2}$. Thiadiazoles and their derivatives exhibit wide range of pharmacological activities such as antimicrobial activity ${ }^{3}$, antidepressant, cardiotonic ${ }^{4}$, antibacterial activity against Klebsiella pneumonia ${ }^{5}$, antitubercular ${ }^{6,7}$, anticonvulsant ${ }^{8}$, antileshmanial, analgesic ${ }^{9}$, antiinflammtory ${ }^{10}$, anticancer ${ }^{11}$, phosphodiesterase inhibitors $^{12}$ and effect on Tyrosinase enzyme ${ }^{13}$. This diversity of biological activity may be due to the presence of $-\mathrm{N}=\mathrm{C}$-S moity ${ }^{14,15}$. There are four isomers of thiadiazole, among these four isomers 1,3,4-thiadiazole is the most thermally stable; which is only isomer doesn't contain any sulphur- nitrogen bond ${ }^{16}$. 1,3,4-thiadiazole relatively stable in aqueous acid solutions but the nucleus can undergo ring cleavage by aqueous base solutions ${ }^{17}$. 
Heterocyclic seven-membered ring constitutes the core or a key fragment of a number of bioactive compounds including isolated from natural products, oxazepine derivatives were found to exhibit a vast variety of biological activities ${ }^{18}$ and found to be a vital moiety in many psychoactive pharmaceuticals ${ }^{19}$. Thus, in this article, we reported here the synthesis of 1,3,4-thiadiazole derivatives containing biologically active oxazepine and benzoxazepine moieties, which might have some biological activity.

\section{EXPERIMENTAL}

\section{General}

The chemicals used were purchased from Merck \& Co., BDH, Sigma Aldrich and $\mathrm{CDH}$ and were used without further purification.Silica TLC plates were used with an aluminum backing $\left(0.2 \mathrm{~mm}, 60 \mathrm{~F}_{254}\right)$. The progress of reactions were monitored by TLC and visualized by development of the TLC plates with iodine vapor. Melting points were determined on an Electro thermal Stuart SMP 30 capillary melting point apparatus. Infrared spectra were recorded on SHIMADZU FTIR-8400S Infrared Spectrophotometer as potassium bromide discs. ${ }^{1} \mathrm{H}$ NMR spectra were collected on NMR spectrometer, Broker 2009 spectrometer at 400 $\mathrm{MHz}$ in DMSO-d6 as solvent and TMS as an internal standard at Kashan University, Iran. Elemental Analysis (CHNS) was carried out with Perkin Elmer 300A Elemental Analyzer at Kashan University, Iran.Azoaldehyde derivatives $4 \mathrm{a}$ and $4 \mathrm{~b}$ were prepared following the method described by Acton $^{20}$.

\section{Chemical methods}

Synthesis of $5,5^{\prime}-\left(\left(\left(1 E, 1^{\prime} E\right)-1,4-p h e n y l e n e b i s\right.\right.$ (methanylidene))bis(azanylylidene))bis(1,3,4thiadiazole-2-thiol) 2:

Terephthaldehyde $(0.67 \mathrm{~g}, 5 \mathrm{mmol})$ was dissolved in $(35 \mathrm{ml})$ of absolute ethanol, then 2-amino-5-mercapto-1,3,4-thiadiazole 1 (1.33 g , $10 \mathrm{mmol}$ ) was added. The reaction mixture was refluxed with stirring on a water bath at $65^{\circ} \mathrm{C}$ for 12 $\mathrm{h}$ and monitored by TLC. The mixture was then allowed to cool down to room temperature, the colored precipitate was filtered and recrystallized

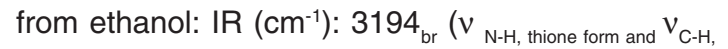
benzene, vib. coupling $), 2972$ and $2885\left(v_{\mathrm{N}-\mathrm{H} \text {, intramolecularly }}\right.$ hydrogen bonded, thione form $), 1691\left(v_{\mathrm{C}=\mathrm{N} \text {, imine }}\right), 1562$ and 1508( $\left.v_{\mathrm{C}=\mathrm{C} \text {, benzene and }} \mathrm{v}_{\mathrm{C}=\mathrm{N} \text {, thiadiazole, vib. coupling }}\right), 1051\left(\mathrm{v}_{\mathrm{C}=\mathrm{S}}\right.$, thione form $), 750$ ( $\left.\delta_{\text {o.o.p. C-H, benzene }}\right) ;{ }^{1} \mathrm{H}$ NMR: $\delta=2.5$ (DMSO solvent), 3.4 ( $\mathrm{H}_{2} \mathrm{O}$ in DMSO), 7.09-8.17 (m, 4H, Ar$\mathrm{H}$ ), 8.8 (s, 2H, $2 \times \mathrm{CH}=\mathrm{N}$, imine), 10.09 (s, 2H, $2 \times \mathrm{N}$ $\mathrm{H}$, thione forms), 13.17 (s, $2 \mathrm{H}, 2 \times \mathrm{S}-\mathrm{H}$, thiol forms) ${ }^{(21)}$

\section{General procedure for the synthesis of oxazepine} and benzoxazepine derivatives (3a, $3 b)$

A mixture of bisimine derivative 2 (0.364 $\mathrm{g}, 1 \mathrm{mmol}$ )and maleic or phthalic anhydride $(2 \mathrm{mmol})$ in dry benzene $(20 \mathrm{ml})$ was refluxed on a water bath at $70^{\circ} \mathrm{C}$ for $20 \mathrm{~h}$ and monitored by TLC. The mixtures were then allowed to cool down to room temperature, the colored precipitates were filtered, dried and recrystallized from ethanol.

2,2'-(1,4-phenylene)bis(3-(5-mercapto-1,3,4thadiazol-2-yl)-2,3-dihydro-1,3-oxazepine-4,7dione) 3a:

IR $\left(\mathrm{cm}^{-1}\right): 3134(v \mathrm{~N}-\mathrm{H}$, thione form), 3007 (vC-H, benzene), $1699(v \mathrm{C}=\mathrm{O}, \mathrm{O}=\mathrm{C}-\mathrm{O}$ and $\mathrm{O}=\mathrm{C}-$ $\mathrm{N}$, oxazepine, vib. coupling), 1564 and 1510 (vC=C, benzene and $\mathrm{vC}=\mathrm{N}$, thiadiazole, vib. coupling),

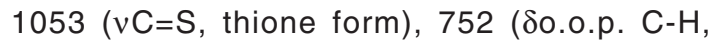
benzene); ${ }^{1} \mathrm{H}$ NMR: $\mathrm{d}$ (ppm) $=6.2$ and 6.6 (ss, $4 \mathrm{H}$, $4 \times$ olefinic $=\mathrm{CH}$, oxazepine), 7.10-8.16 $(\mathrm{m}, 6 \mathrm{H}, \mathrm{Ar}-\mathrm{H}$ and $\mathrm{C}-\mathrm{H}$, oxazepine), 10.1 (s, $2 \mathrm{H}, 2 \times \mathrm{N}-\mathrm{H}$, thione forms, $13.2\left(\mathrm{~s}, 2 \mathrm{H}, 2 \times \mathrm{S}-\mathrm{H}\right.$, thiol forms ${ }^{21}$. The singlet signals around $2.5 \mathrm{ppm}$ and $3.3 \mathrm{ppm}$ attributed to DMSO and absorbed $\mathrm{H}_{2} \mathrm{O}$ in DMSO, respectively.Anal.Calcd.for $\mathrm{C}_{20} \mathrm{H}_{12} \mathrm{~N}_{6} \mathrm{O}_{6} \mathrm{~S}_{4}: \mathrm{C}, 42.85 ; \mathrm{H}, 2.16 ; \mathrm{N}, 14.99 ; \mathrm{S}, 22.88$ Found C, 42.52; H, 2.19; N, 15.22; S, 22.51.

3,3'-(1,4-phenylene)bis(4-(5-mercapto-1,3,4thadiazol-2-yl) - 3, 4 - di h y d r obenzo [e] [1,3]oxazepine-1,5-dione) 3b:

IR $\left(\mathrm{cm}^{-1}\right): 3144(\mathrm{vN}-\mathrm{H}$, thione form), 3076 and $3016\left(\mathrm{vC}-\mathrm{H}\right.$, benzene), 2989 and $2895\left(\mathrm{v}_{\mathrm{N}-\mathrm{H},}\right.$ intramolecularly hydrogen bonded, thione form $), 2740$ ( $v \mathrm{C}-\mathrm{H}$, oxazepine), 2654 and 2526 (vS-H, thiol form), 1695 ( $\vee \mathrm{C}=\mathrm{O}, \mathrm{O}=\mathrm{C}-\mathrm{O}$ and $\mathrm{O}=\mathrm{C}-\mathrm{N}$, oxazepine, vib. coupling), 1564 and 1498 ( $\vee \mathrm{C}=\mathrm{C}$, benzene and $v \mathrm{C}=\mathrm{N}$, thiadiazole, vib. coupling), 1062 ( $\vee \mathrm{C}=\mathrm{S}$, thione form), 798 and

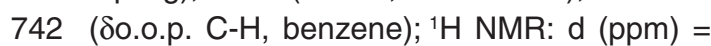
7.08-8.14 (m, 14H, Ar-H and $\mathrm{C}-\mathrm{H}$, oxazepine), 10.1 (s, $2 \mathrm{H}, 2 \times \mathrm{N}-\mathrm{H}$, thione forms), 13.16 (s, $2 \mathrm{H}$, $2 \times \mathrm{S}-\mathrm{H}$, thiol forms). The singlet signals around $2.5 \mathrm{ppm}$ and $3.3 \mathrm{ppm}$ attributed to DMSO and absorbed $\mathrm{H}_{2} \mathrm{O}$ in DMSO, respectively. 
Anal.Calcd. for $\mathrm{C}_{28} \mathrm{H}_{16} \mathrm{~N}_{6} \mathrm{O}_{6} \mathrm{~S}_{4}: \mathrm{C}, 50.90 ; \mathrm{H}, 2.44$; $\mathrm{N}, 12.72 ; \mathrm{S}, 19.41$ Found $\mathrm{C}, 51.23 ; \mathrm{H}, 2.62 ; \mathrm{N}$, $12.43 ; \mathrm{S}, 19.55$.

\section{Synthesis of azo-aldehyde derivatives $(4 a, 4 b)$ :} were prepared following the method described by Acton $^{20}$.

2-hydroxy-5-((5-mercapto-1,3,4-thiadiazolyl)diazenyl)benzaldehyde $4 a$ :

IR $\left(\mathrm{cm}^{-1}\right): 3281_{\text {br }}\left(v_{\text {O-H }}\right), 3093\left(v_{\text {N-H, thione form }}\right.$

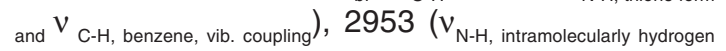
bonded, thione form $), 1629\left(v_{C=0 \text {, aldehyde }}\right), 1556$ and $1498(v$ $\mathrm{C}=\mathrm{C}$, benzene and $\left.\mathrm{v}_{\mathrm{C}=\mathrm{N} \text {, thiadiazole, vib. coupling }}\right), \quad 1037\left(\mathrm{v}_{\mathrm{C}=\mathrm{S} \text {, thione }}\right.$ $\left.\begin{array}{l}\mathrm{C}=\mathrm{C} \text {, benzene and } \\ \text { form }\end{array}\right), 833\left(\delta_{\text {o.o.p. }} \mathrm{C}\right.$-H, benzene $\left.\left.)\right)\right) ;{ }^{1} \mathrm{H}$ NMR: $\mathrm{d}(\mathrm{ppm})=6.93-$ $7.81(\mathrm{~m}, 3 \mathrm{H}, \mathrm{Ar}-\mathrm{H}), 10.2(\mathrm{~s}, 1 \mathrm{H}, \mathrm{O}=\mathrm{CH}$, aldehyde), $10.7(\mathrm{~s}, 1 \mathrm{H}, \mathrm{O}-\mathrm{H}), 13.1(\mathrm{~s}, 1 \mathrm{H}, \mathrm{S}-\mathrm{H})^{20}$. The singlet signals around $2.48 \mathrm{ppm}$ and $3.85 \mathrm{ppm}$ attributed to DMSO and absorbed $\mathrm{H}_{2} \mathrm{O}$ in DMSO, respectively.

\section{4-hydroxy-5-((5-mercapto-1,3,4-thiadiazol-} yl)diazenyl)benzaldehyde $4 \mathrm{~b}$ :

$\operatorname{IR}\left(\mathrm{cm}^{-1}\right): 3284_{\mathrm{br}}\left(v_{\mathrm{O}-\mathrm{H}}\right), 3095_{\mathrm{br}}\left(v_{\mathrm{N}-\mathrm{H} \text {, thione form }}\right.$ and $\left.v_{\text {C-H, benzene, vib. coupling }}\right), 2962$ and $2899\left(v_{\mathrm{N}-\mathrm{H}}\right.$, intramolecularly hydrogen bonded, thione form $), 2829$ and $2700\left(v_{\mathrm{C}-\mathrm{H},}\right.$ aldehyde $), 1627\left(v_{\mathrm{C}=\mathrm{O} \text {, aldehyde }}\right), 1552$ and $1498\left(v_{\mathrm{C}=\mathrm{C},}\right.$ benzene and $\left.v_{\mathrm{C}=\mathrm{N} \text {, thiadiazole, vib. coupling }}\right), \quad 1039\left(v_{\mathrm{C}=\mathrm{S} \text {, thione form }}\right)$,

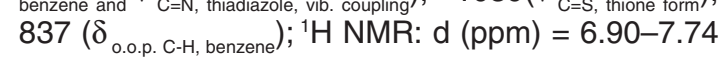
$(\mathrm{m}, 3 \mathrm{H}, \mathrm{Ar}-\mathrm{H}), 8.8(\mathrm{~s}, 1 \mathrm{H}, \mathrm{O}-\mathrm{H}), 9.7(\mathrm{~s}, 1 \mathrm{H}, \mathrm{O}=\mathrm{CH}$, aldehyde), 12.34 (s, 1H, S-H)

\section{General procedure for the synthesis of azoimine derivatives $(5 a, 5 b)$ :}

Azoaldehyde derivatives $4 a$ or $4 b(0.665$ $\mathrm{g}, 2.5 \mathrm{mmol}$ ) was dissolved in $(30 \mathrm{ml})$ of absolute ethanol, then 2-amino-5-mercapto-1,3,4thiadiazole $1(0.3325 \mathrm{~g}, 2.5 \mathrm{mmol})$ was added. The reaction mixtures were refluxed with stirring on a water bath at $65^{\circ} \mathrm{C}$ for $10 \mathrm{~h}$ and monitored by TLC. The mixtures were then allowed to cool down to room temperature, the colored precipitates were filtered and recrystallized from ethanol.

4-((E)-(5-mercapto-1,3,4-thiadiazol-2-yl)diazenyl2-((E)-((5-mercapto-1,3,4-thiadiazole-2yl)imino)methyl)phenol 5a:

$\mathrm{IR}\left(\mathrm{cm}^{-1}\right): 3269_{\mathrm{br}}\left(\mathrm{vO}_{\mathrm{v}-\mathrm{H}}\right), 3109\left(_{\mathrm{v}-\mathrm{H}, \text { thione form and }}\right.$
vC-H, benzene, vib. coupling $), 2943\left(\mathrm{i}_{\mathrm{N}-\mathrm{H}, \text { intramolecularly hydrogen bonded, }}\right.$

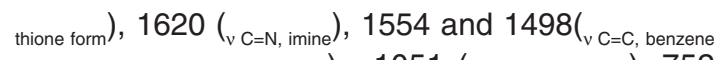
and $v \mathrm{C}=\mathrm{N}$, thiadiazole, vib. coupling $), 1051(\mathrm{v} C=\mathrm{S}$, thione form $), 752$ $\left({ }_{\text {so.o.p. C. }}\right.$-H, benzene $) ;{ }^{1} \mathrm{H}$ NMR: $\mathrm{d}(\mathrm{ppm})=7.00-7.77(\mathrm{~m}$, $4 \mathrm{H}, \mathrm{Ar}-\mathrm{H}$ and $\mathrm{HC}=\mathrm{N}$, imine), $10.2(\mathrm{~s}, 1 \mathrm{H}, \mathrm{O}-\mathrm{H})$, $13.16(\mathrm{~s}, 2 \mathrm{H}, 2 \times \mathrm{S}-\mathrm{H})^{20}$.

2-((E)-(5-mercapto-1,3,4-thiadiazol-2-yl)diazenyl4-((E)-((5-mercapto-1,3,4-thiadiazole-2yl)imino)methyl)phenol $5 \mathrm{~b}$ :

$\operatorname{IR}\left(\mathrm{cm}^{-1}\right): 3267_{\mathrm{br}}\left(v_{\mathrm{O}-\mathrm{H}}\right), 3099_{\mathrm{br}}\left(v_{\mathrm{N}-\mathrm{H}, \text { thione form }}\right.$ and $\left.v_{C-H, \text { benzene, vib. coupling }}\right), 2949$ and $2802\left(v_{\mathrm{N}-\mathrm{H}}\right.$, intramolecularly hydrogen bonded, thione form $), 2584\left(v_{S-H}\right), 1610\left(_{v}\right.$ $\mathrm{C}=\mathrm{N}$, imine $), 1554$ and $1502\left(\mathrm{v}_{\mathrm{C}=\mathrm{C} \text {, benzene and }} \mathrm{v}_{\mathrm{C}=\mathrm{N}, \text { thiadiazole, vib. }}\right.$ coupling $), \quad 1051\left(v_{\mathrm{C}=\mathrm{S}, \text { thione form }}\right), 752$ and $715\left(\delta_{\text {o.o.p. }} \mathrm{C}-\mathrm{H}\right.$, benzene); ${ }^{1} \mathrm{H}$ NMR: $\mathrm{d}(\mathrm{ppm})={ }^{1} \mathrm{H}$ NMR: $\mathrm{d}(\mathrm{ppm})=6.9-$ $7.7(\mathrm{~m}, 3 \mathrm{H}, \mathrm{Ar}-\mathrm{H}), 8.8(\mathrm{~s}, 1 \mathrm{H}, \mathrm{N}=\mathrm{CH}$, imine $), 9.6$ and 9.7 (ss, $2 \mathrm{H}, 2 \times \mathrm{N}-\mathrm{H}$, thione forms), $10.5(\mathrm{~s}, 1 \mathrm{H}$, $\mathrm{O}-\mathrm{H}), 13.4$ (s, 2H, 2xS-H, thiol forms).

\section{General procedure for the synthesis of oxazepine} and benzoxazepine derivatives $6 a-d$ :

A mixture of azoimine derivatives $5 a$ or $5 b$ $(0.381 \mathrm{~g}, 1 \mathrm{mmol})$ and maleic or phthalic anhydride $(1 \mathrm{mmol})$ in dry benzene $(20 \mathrm{ml})$ was refluxed on a water bath at $70^{\circ} \mathrm{C}$ for $24 \mathrm{~h}$. and monitored by TLC. The mixtures were then allowed to cool down to room temperature, the colored precipitates were filtered, dried and recrystallized from ethanol.

2-(2-hydroxy-5-((5-mercapto-1,3,4-thiadiazole-2yl)diazenyl)phenyl)-3-(5-mercapto-1,3,4thiadiazole-2-yl)-2,3-dihydro-1,3-oxazepine-4,7dione 6a:

IR $\left(\mathrm{cm}^{-1}\right): 3280_{b r}(v O-H), 3105_{b r}(v N-H$, thione form and $v \mathrm{C}-\mathrm{H}$, benzene, vib. coupling), 2949 and $2791\left(v_{\mathrm{N}-\mathrm{H} \text {, intramolecularly hydrogen bonded, thione form }}\right)$, $2708\left(\mathrm{vC}-\mathrm{H}\right.$, oxazepine), $2536\left(v_{\mathrm{S}-\mathrm{H}}\right), 1640(\mathrm{vC}=\mathrm{O}$, $\mathrm{O}=\mathrm{C}-\mathrm{O}$ and $\mathrm{O}=\mathrm{C}-\mathrm{N}$, oxazepine, vib. coupling), 1552 and $1498(\mathrm{vC}=\mathrm{C}$, benzene and $\mathrm{vC}=\mathrm{N}$, thiadiazole,

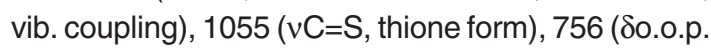
$\mathrm{C}-\mathrm{H}$, benzene); ${ }^{1} \mathrm{H}$ NMR: $\mathrm{d}(\mathrm{ppm})=6.2$ and 6.6 (ss, $2 \mathrm{H}, 2 \times$ olefinic $=\mathrm{CH}$, oxazepine $), 7.13-8.19(\mathrm{~m}, 4 \mathrm{H}$, $\mathrm{Ar}-\mathrm{H}$ and $\mathrm{C}-\mathrm{H}$, oxazepine), $10.35(\mathrm{~s}, 1 \mathrm{H}, \mathrm{O}-\mathrm{H})$, $13.16(\mathrm{~s}, 2 \mathrm{H}, 2 \times \mathrm{S}-\mathrm{H})$. The singlet signals around $2.47 \mathrm{ppm}$ and $3.49 \mathrm{ppm}$ attributed to DMSO and absorbed $\mathrm{H}_{2} \mathrm{O}$ in DMSO. Anal.Calcd.for $\mathrm{C}_{15} \mathrm{H}_{9} \mathrm{~N}_{7} \mathrm{O}_{4} \mathrm{~S}_{4}$ : C, 37.57; H, 1.89; N, 20.45; S, 26.75 Found C, 37.28; H, 2.09; N, 20.22; S, 26.47. 
(E)-3-(2-hydroxy-3-((5-mercapto-1,3,4thiadiazole-2-yl) diazenyl) phenyl)-4-(5-mercapto1,3,4-thiadiazole-2-yl)-3,4-dihydrobenzo [e] [1,3] oxazepine-1,5-dione $6 \mathrm{~b}$ :

IR $\left(\mathrm{cm}^{-1}\right): 3267 \mathrm{br}(\mathrm{vO}-\mathrm{H}), 3086_{\mathrm{br}}(\mathrm{vN}-\mathrm{H}$, thione form and $\mathrm{vC}-\mathrm{H}$, benzene, vib. coupling), 2955 and $2806\left(v_{\mathrm{N}-\mathrm{H}, \text { intramolecularly hydrogen bonded, thione form }}\right), 2700$ ( $v \mathrm{C}-\mathrm{H}$, oxazepine), $2525\left(v_{\mathrm{s}-\mathrm{H}}\right), 1691(\mathrm{v}=\mathrm{O}, \mathrm{O}=\mathrm{C}-$ O, oxazepine), 1631 ( $\mathrm{O}=\mathrm{C}-\mathrm{N}$, oxazepine), 1554 and $1500(v C=C$, benzene and $v \mathrm{C}=\mathrm{N}$, thiadiazole, vib. coupling), 1062 ( $(\mathrm{C}=\mathrm{S}$, thione form), 798 ( $\delta$ o.o.p. $\mathrm{C}-\mathrm{H}$, benzene); ${ }^{1} \mathrm{H}$ NMR: $\mathrm{d}(\mathrm{ppm})=7.34-7.64(\mathrm{~m}$, $8 \mathrm{H}, \mathrm{Ar}-\mathrm{H}$ and $\mathrm{C}-\mathrm{H}$, oxazepine), $7.79(\mathrm{~s}, 1 \mathrm{H}, \mathrm{O}-\mathrm{H})$, 13.16 (s, 2H, 2xS-H)..Anal.Calcd.for $\mathrm{C}_{19} \mathrm{H}_{11} \mathrm{~N}_{7} \mathrm{O}_{4}$ $\mathrm{S}_{4}$ : C, 43.09; H, 2.09; N, 18.51; S, 24.22 Found C, 43.36; H, 2.22; N, 18.21; S, 24.54.

2-(4-hydroxy-3-((5-mercapto-1,3,4-thiadiazole-2yl)diazenyl)phenyl)-3-(5-mercapto-1,3,4thiadiazole-2-yl)-2,3-dihydro-1,3-oxazepine-4,7dione 6c:

IR $\left(\mathrm{cm}^{-1}\right): 3281_{b r}(\mathrm{vO}-\mathrm{H}), 3078(\mathrm{vN}-\mathrm{H}$, thione form and $v \mathrm{C}-\mathrm{H}$, benzene, vib. coupling), 2962 and $2891\left(v_{\mathrm{N}-\mathrm{H}, \text { intramolecularly hydrogen bonded, thione form }}\right), 2829(\mathrm{vC}-$ $\mathrm{H}$, oxazepine), 1705 ( $\mathrm{vC}=\mathrm{O}, \mathrm{O}=\mathrm{C}-\mathrm{O}$, oxazepine), 1631 ( $\mathrm{O}=\mathrm{C}-\mathrm{N}$, oxazepine), 1550 and 1500 ( $\mathrm{vC}=\mathrm{C}$, benzene and $v \mathrm{C}=\mathrm{N}$, thiadiazole, vib. coupling), 1039

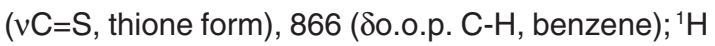
NMR: $\mathrm{d}(\mathrm{ppm})=6.24$ and 6.59 (ss, $2 \mathrm{H}, 2 \times$ olefinic $=\mathrm{CH}$, oxazepine $), 7.13-7.32(\mathrm{~m}, 4 \mathrm{H}, \mathrm{Ar}-\mathrm{H}$ and $\mathrm{C}-$ $\mathrm{H}$, oxazepine), $8.78(\mathrm{~s}, 1 \mathrm{H}, \mathrm{O}-\mathrm{H}), 9.5(\mathrm{~s}, 2 \mathrm{H}, 2 \times \mathrm{S}-$ H).Anal.Calcd. For $\mathrm{C}_{15} \mathrm{H}_{9} \mathrm{~N}_{7} \mathrm{O}_{4} \mathrm{~S}_{4}: \mathrm{C}, 37.57 ; \mathrm{H}, 1.89$; N, 20. 45 ; S, 26.75 Found C, 37.32; H, 2.06; N, 20.14; S, 27.07.

(E)-3-(4-hydroxy-3-((5-mercapto-1,3,4thiadiazole-2-yl)diazenyl)phenyl)-4-(5-mercapto1,3,4-thiadiazole-2-yl)-3,4-dihydrobenzo [e] [1,3]oxazepine-1,5-dione 6d:

IR $\left(\mathrm{cm}^{-1}\right): 3277_{\mathrm{br}}(\mathrm{vO}-\mathrm{H}), 3091(\mathrm{vN}-\mathrm{H}$, thione form and íC-H, benzene, vib. coupling), 2954 $\left(v_{\mathrm{N}-\mathrm{H}, \text { intramolecularly hydrogen bonded, thione form }}\right), 2655(\mathrm{vC}-\mathrm{H}$, oxazepine), $2530(\mathrm{vS}-\mathrm{H}), 1691(\mathrm{vC}=\mathrm{O}, \mathrm{O}=\mathrm{C}-\mathrm{O}$, oxazepine), 1629 ( $\mathrm{O}=\mathrm{C}-\mathrm{N}$, oxazepine), 1552 and $1500(v C=C$, benzene and $v C=N$, thiadiazole, vib. coupling), 1070 and 1055 ( $\mathrm{vC}=\mathrm{S}$, thione forms), 802 and 740 (\$o.o.p. C-H, benzene); ${ }^{1} \mathrm{H}$ NMR: $\mathrm{d}(\mathrm{ppm})=7.34-$ $7.65(\mathrm{~m}, 8 \mathrm{H}, \mathrm{Ar}-\mathrm{H}$ and $\mathrm{C}-\mathrm{H}$, oxazepine), 7.80 (s, 1H, O$\mathrm{H}), 13.16(\mathrm{~s}, 2 \mathrm{H}, 2 \times \mathrm{S}-\mathrm{H})$.Anal.Calcd. For $\mathrm{C}_{19} \mathrm{H}_{11} \mathrm{~N}_{7} \mathrm{O}_{4} \mathrm{~S}_{4}$ : C, 43.09; H, 2.09; N, 18.51; S, 24.22 Found C, 42.88; H, $2.15 ; \mathrm{N}, 18.77 ; \mathrm{S}, 24.48$.

\section{RESULTS AND DISCUSSION}

\section{Chemistry}

The precursor bisimine2 was synthesized by reacting terephthaldehyde with 2-amino-5mercapto-1,3,4-thiadiazole 1 in absolute ethanol. Compound 2 was reacted with maleic and phthalic anhydrides to give the bis-1,3-oxazepine and bis1,3-benzoxazepine derivatives of 1,3,4-thiadiazole $3 a$ and $3 b$ respectively in Scheme (1). The proposed mechanism for the addition of cyclic anhydride to imine was shown in Scheme (2).

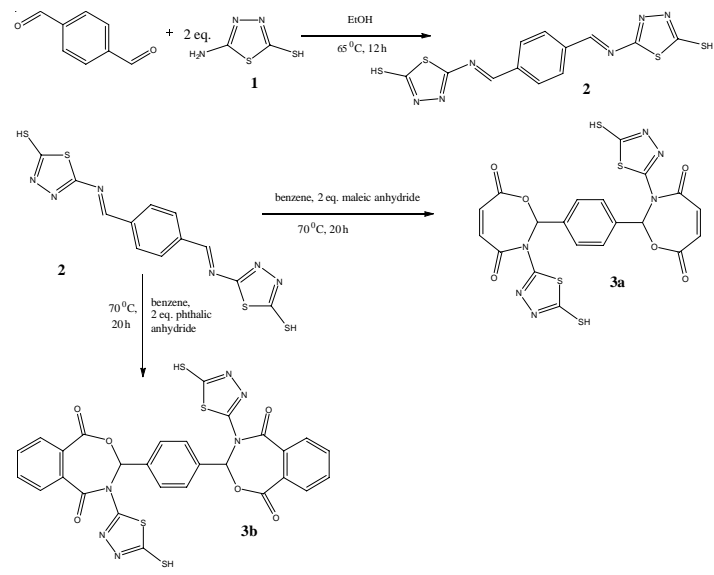

Scheme. 1. Synthesis of oxazepines $3 a$ and $3 b$.

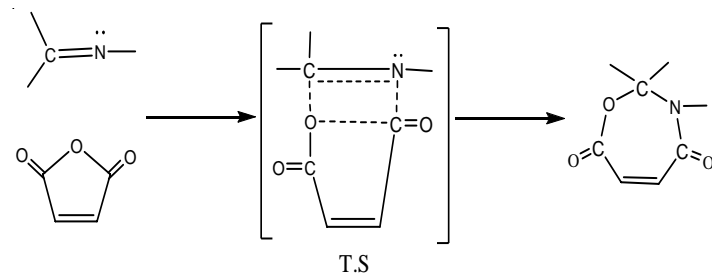

Scheme. 2. Proposedmechani sm for the formation of oxazepinering.

The chemical structures of these newly oxazepines were confirmed by IR, ${ }^{1} \mathrm{H}$ NMR spectral measurements and (CHNS) elemental analysis and were in good agreement with the proposed structures.

The IR spectrum of bis-imine 2 showed the stretching absorption band of the $(\mathrm{C}=\mathrm{N})$ function at $1691 \mathrm{~cm}^{-1}$, while the absorption bands due to $\left(\mathrm{NH}_{2}\right)$ group at 3336 and $3267 \mathrm{~cm}^{-1}$ have disappeared.The broad absorption band at 3194 attributed to the $(\mathrm{N}-\mathrm{H}) \mathrm{str}$. in thione form. The stretching band of $(\mathrm{C}=\mathrm{S})$ function in thione form 
appeared as strong band at $1051 \mathrm{~cm}^{-1}$. The IR spectra of compounds $3 \mathrm{a}$ and $3 \mathrm{~b}$ indicated the absence of $(\mathrm{C}=\mathrm{N})$ absorption band and the appearance of $(\mathrm{C}=\mathrm{O})$ str. for oxazepine ring at 1699 and $1695 \mathrm{~cm}^{-1}$, respectively.

The ${ }^{1} \mathrm{H}$ NMR spectrum of bisimine 2 showed the $(\mathrm{HC}=\mathrm{N})$ protons as a singlet at $\delta 8.8$ ppm, the $(\mathrm{N}-\mathrm{H})$ protons of thione forms appeared as a singlet at $10.09 \mathrm{ppm}$, the (Ar-H) protons at $\delta$ $7.09-8.17 \mathrm{ppm}$. Moreover, the spectrum showed the $(\mathrm{SH})$ protons asa singlet at $13.17 \mathrm{ppm}{ }^{21}$.

The ${ }^{1} \mathrm{H}$ NMR spectra of oxazepine compounds $3 \mathrm{a}$ and $3 \mathrm{~b}$ showed the disappearance of the $(\mathrm{CH}=\mathrm{N})$ protons at $8.8 \mathrm{ppm}$, the thioic $(\mathrm{S}-\mathrm{H})$ protons appeared as a singlet at $\delta 13.2$ and 13.16 $\mathrm{ppm}$, respectively. The $(\mathrm{N}-\mathrm{H})$ protons for thione forms as a singlet at 10.1. The signals of aromatic protons
$(\mathrm{Ar}-\mathrm{H})$ and $(\mathrm{C}-\mathrm{H})$ protons of oxazepine rings appeared at $\delta 7.08-8.16 \mathrm{ppm}$. Moreover, the olefinic $(=\mathrm{CH})$ protons of the oxazepine rings in compound 3a appeared as singlet at 6.2 and $6.6 \mathrm{ppm}$.

The initiators azoaldehydes $4 a$ and $4 b$ were synthesized by reacting the diazonium salt of 2-amino-5-mercapto-1,3,4-thiadiazole 1 with alkaline solutions of 2-hydroxybenzaldehyde and 4-hydroxybenzaldehyde respectively using the method described by acton ${ }^{(20)}$. The resulting aldehydes $4 \mathrm{a}$ and $4 \mathrm{~b}$ werecondensed with 2-amino-5-mercapto-1, 3, 4-thiadiazole 1 in absolute ethanol to give the azoimine derivatives $5 a$ and $5 b$ respectively. The resulting imines $5 a$ and $5 \mathrm{~b}$ were allowed to react with maleic and phthalic anhydrides leading to the formation of oxazepine1,3,4-thiadiazole derivatives $6 a-d$ respectively (Scheme 4).
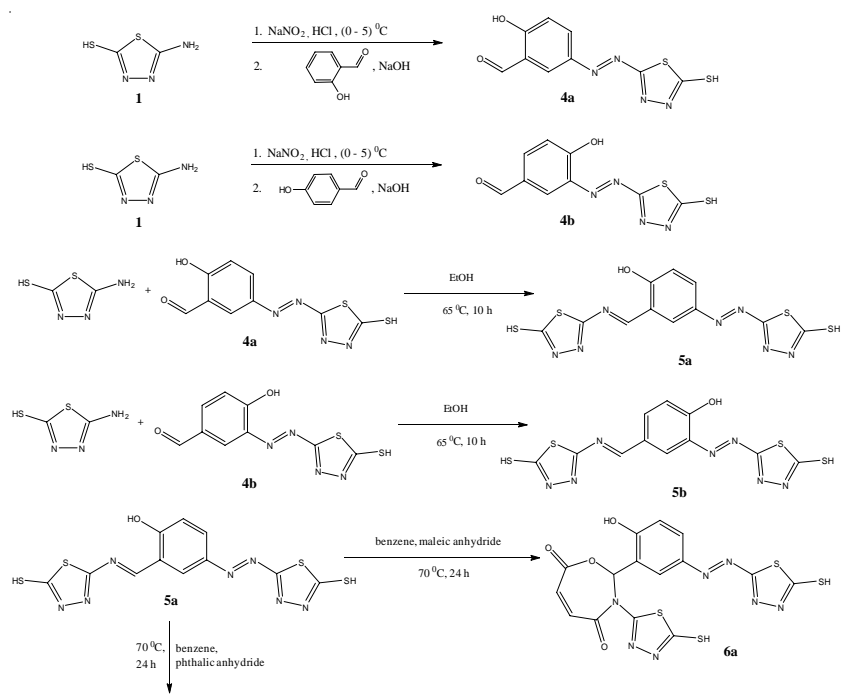<smiles>CC1CCC(CCC2CCC(C)C(C3CC(C)CC4CCCC4C3C)C2C2CCC(C)C2)CC1</smiles><smiles>CC(C)C(C)C(C)C</smiles><smiles>O=C1OC(c2ccc(O)c(N=Nc3nnc(Br)s3)c2)N(c2nnc(Br)s2)C(=O)c2ccccc21</smiles>

Scheme. 3. Synthesis of oxazepines 6a-d. 
The structures of the compounds synthesized were deduced by IR, ${ }^{1} \mathrm{H}$ NMR spectral measurements and (CHNS) elemental analysis and were in good agreement with the proposed structures.

The IR spectra of azoaldehde derivatives $4 a$ and $4 b$ indicated the absence of the doublet band at 3336 and $3267 \mathrm{~cm}^{-1}$ for $\left(-\mathrm{NH}_{2}\right)$ str. and appearance of broad band at 3281 and $3284 \mathrm{~cm}^{-1}$ assigned to $(\mathrm{O}-\mathrm{H})$ str., the absorption band at 1629 and $1627 \mathrm{~cm}^{-1}$ belong to the aldehydic $(\mathrm{C}=\mathrm{O})$ str., respectively. The IR spectra of imine derivatives $5 \mathrm{a}$ and $5 \mathrm{~b}$ showed the disappearance of the absorption bands at 1629 and $1627 \mathrm{~cm}^{-1}$ for aldehydic $(\mathrm{C}=\mathrm{O})$ str., also disappearing the doublet band for $\left(-\mathrm{NH}_{2}\right)$ str. in 2-amino-5-mercapto-1,3,4-thiadiazole at 3336 and $3267 \mathrm{~cm}^{-1}$, while the absorption bands attributed to $(\mathrm{C}=\mathrm{N})$ str.appeared at 1620 and $1610 \mathrm{~cm}^{-1}$, respectively. In the IR spectra of oxazepine compounds 6a-d, the stretching absorption band due to the stretching of $(\mathrm{C}=\mathrm{O}$, oxazepine) was found at 1640, (1691 and 1631), (1705 and 1631), (1691 and 1629$) \mathrm{cm}^{-1}$, respectively, while the absorption bands due to $(\mathrm{C}=\mathrm{N})$ str. at 1620 and $1610 \mathrm{~cm}^{-1}$ have disappeared.

The ${ }^{1} \mathrm{H}$ NMR spectra of azoaldehyde compounds $4 \mathrm{a}$ and $4 \mathrm{~b}$ showed the $(\mathrm{S}-\mathrm{H})$ proton as a singlet at $\delta 13.1$ and $12.34 \mathrm{ppm}^{20}$.the $(\mathrm{O}-\mathrm{H})$ proton appeared as a singlet at 10.7 and $8.8 \mathrm{ppm}$, the $(\mathrm{HC}=\mathrm{O})$ proton as a singlet at $\delta 10.2$ and $9.7 \mathrm{ppm}$, , the $(\mathrm{Ar}-\mathrm{H})$ protons at $\delta 6.90-7.81 \mathrm{ppm}$.

The ${ }^{1} \mathrm{H}$ NMR spectra of imine compounds $5 \mathrm{a}$ and $5 \mathrm{~b}$ showed the $(\mathrm{S}-\mathrm{H})$ proton as a singlet at $\delta 13.6$ and $13.4 \mathrm{ppm}$, the $(\mathrm{O}-\mathrm{H})$ proton appeared as a singlet at 10.2 and $10.5 \mathrm{ppm}$, the $(\mathrm{HC}=\mathrm{N})$ proton as a singlet at $\delta 7.77$ and $8.8 \mathrm{ppm}$, , the $(\mathrm{Ar}-\mathrm{H})$ protons at $\delta 6.90-7.77 \mathrm{ppm}$.

Table. 1: Physical Properties Of The Synthesized Compounds.

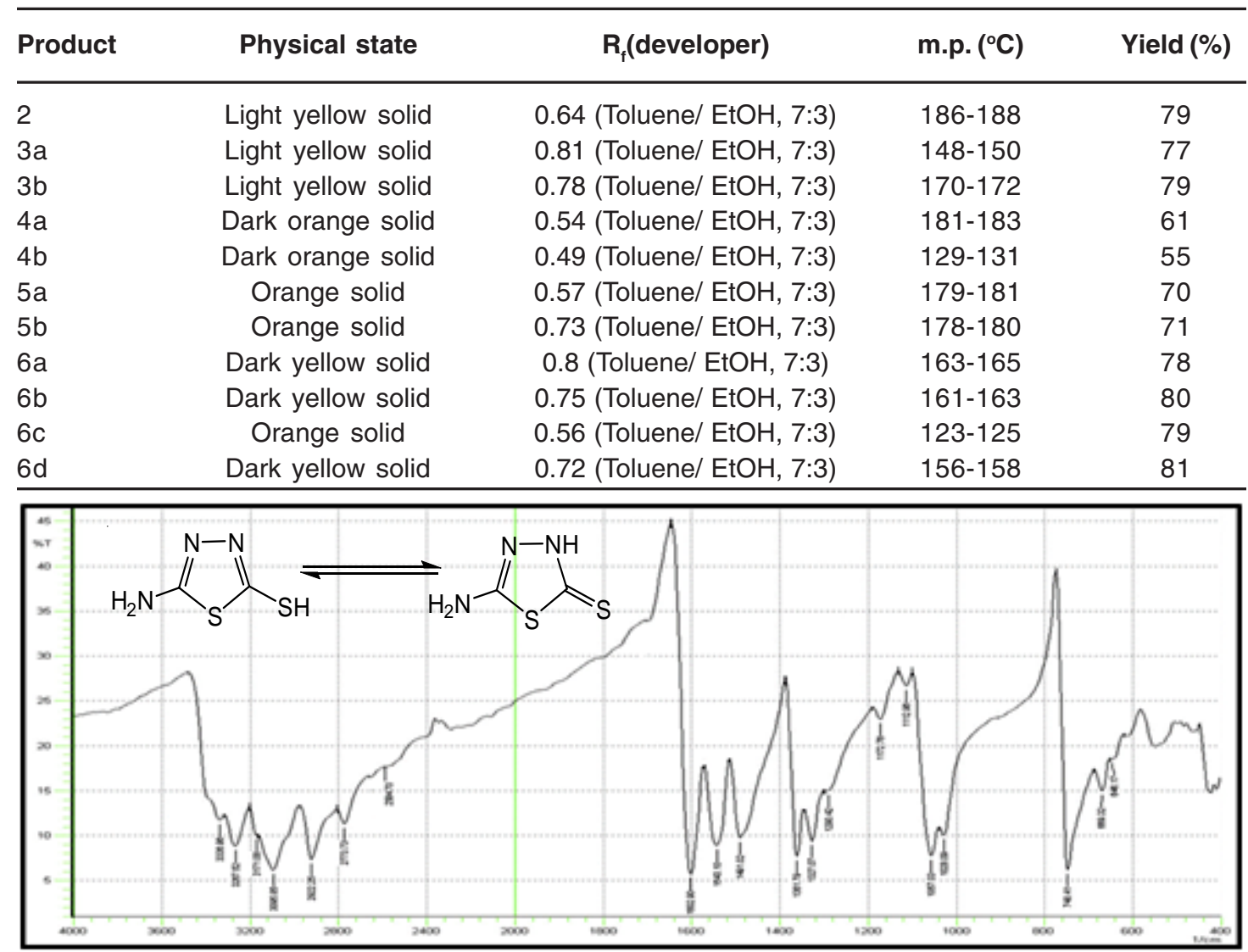

Fig. 1. FTIR spectrum of compound 1 


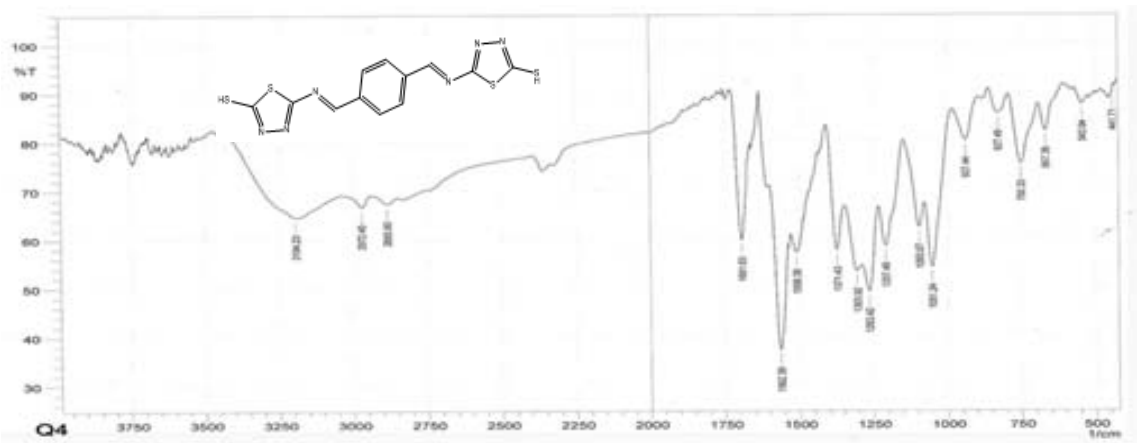

Figu. 2. FTIR spectrum of compound 2

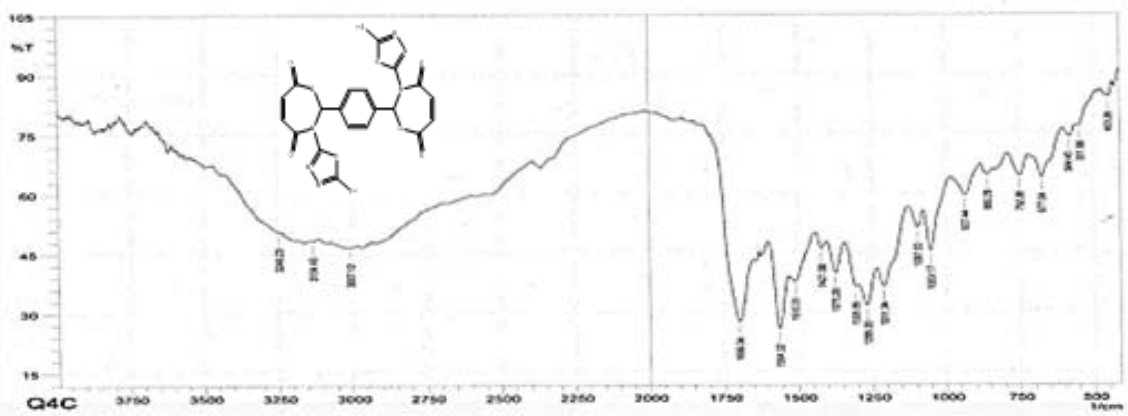

Fig. 3. FTIR spectrum of compound 3a

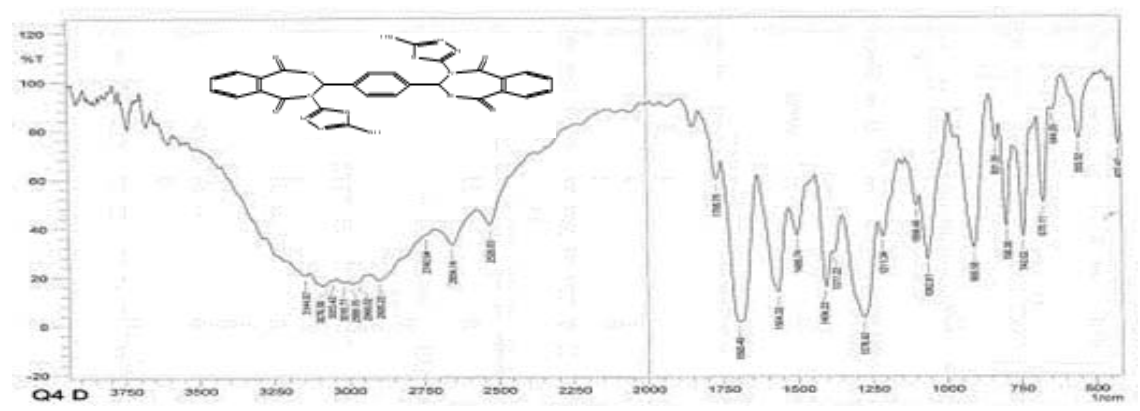

Fig. 4. FTIR spectrum of compound $3 b$

The ${ }^{1} \mathrm{H}$ NMR spectra of oxazepine compounds $6 \mathrm{a}-\mathrm{d}$ showed the disappearance of the $(\mathrm{CH}=\mathrm{N})$ protons at 7.77 and $8.8 \mathrm{ppm}$, the $(\mathrm{S}-\mathrm{H})$ proton appeared as a singlet at $\delta 13.6,13.6,9.5$ and $13.16 \mathrm{ppm}$, respectively. The $(\mathrm{O}-\mathrm{H})$ proton as a singlet at $10.35,7.79,8.78$ and $7.80 \mathrm{ppm}$. The signals of aromatic protons $(\mathrm{Ar}-\mathrm{H})$ and $(\mathrm{C}-\mathrm{H})$ proton of oxazepine rings appeared at $\delta 7.13-8.19 \mathrm{ppm}$. Moreover, the olefinic $(=\mathrm{CH})$ protons of the oxazepine ring in compounds $6 \mathrm{a}$ and $6 \mathrm{c}$ appeared as a singlets at $(6.2,6.6)$ and $(6.24,6.59) \mathrm{ppm}$, respectively.

The structures of the compounds synthesized were proven by IR, ${ }^{1} \mathrm{H}$ NMR spectral measurements and (CHNS) elemental analysis and were in good agreement with the proposed structures.

The IR spectrum of bis-azoaldehde derivative 7 showed disappearance of the sharp doublet band for $\left(-\mathrm{NH}_{2}\right)$ str. at the range (3400-3250) $\mathrm{cm}^{-1}$ and appearance of band at $3365 \mathrm{~cm}^{-1}$ assigned to $(\mathrm{O}-\mathrm{H})$ str., the strong absorption band at $1662 \mathrm{~cm}$ ${ }^{1}$ due to the aldehydic $(\mathrm{C}=\mathrm{O})$ str. The IR spectrum of bis-imine derivative 8 indicated the disappearance of the absorption band at $1662 \mathrm{~cm}^{-1}$ for aldehydic $(\mathrm{C}=\mathrm{O})$ str., also disappearing the doublet band for ($\mathrm{NH}_{2}$ )str. in 2-amino-5-mercapto-1,3,4-thiadiazole at 3336 and $3267 \mathrm{~cm}^{-1}$, while the absorption band 
attributed to $(\mathrm{C}=\mathrm{N})$ str.appeared at $1602 \mathrm{~cm}^{-1}$. The IR spectra of oxazepine compounds $9 \mathrm{a}$ and $9 \mathrm{~b}$ showedthe stretching absorption band due to $(\mathrm{C}=\mathrm{O}$, oxazepine $)$ at $(1714,1662) \mathrm{cm}^{-1}$ and 1689 $\mathrm{cm}^{-1}$ respectively, while the absorption band due to $(\mathrm{C}=\mathrm{N})$ at $1602 \mathrm{~cm}^{-1}$ has disappeared.
The biological activity of the synthesized oxazepines of 1,3,4-thiadiazole $3 a$, 3b and6a-dwill be measured in subsequent study.

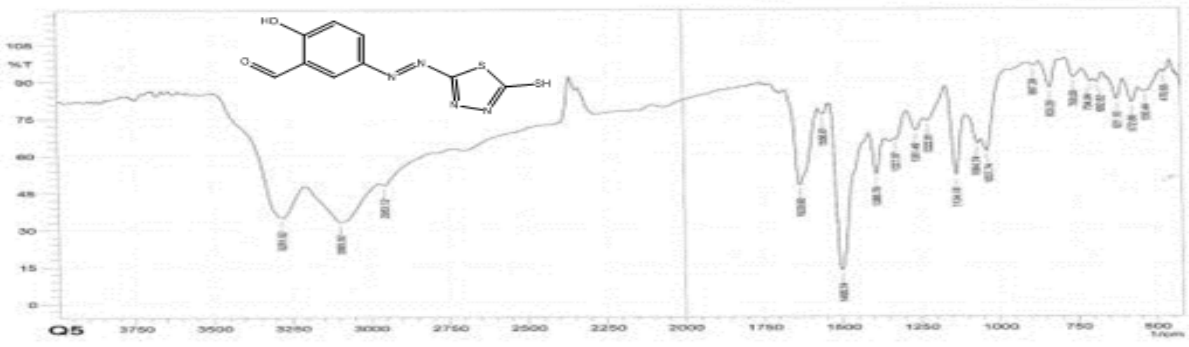

Fig. 5. FTIR spectrum of compound $4 a$

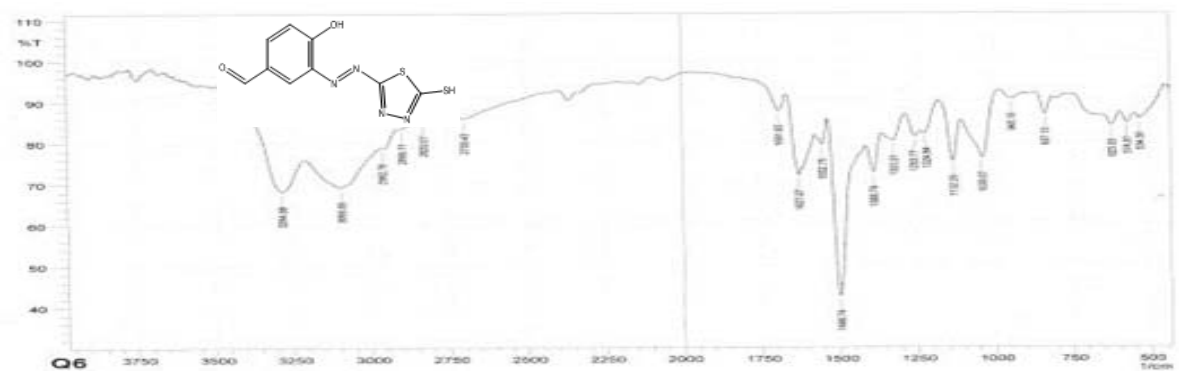

Fig. 6. FTIR spectrum of compound $4 \mathrm{~b}$

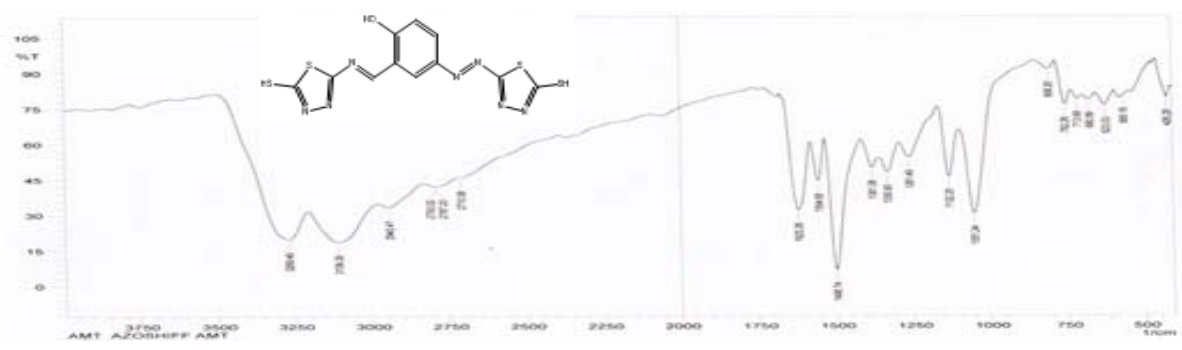

Fig. 7. FTIR spectrum of compound 5 a

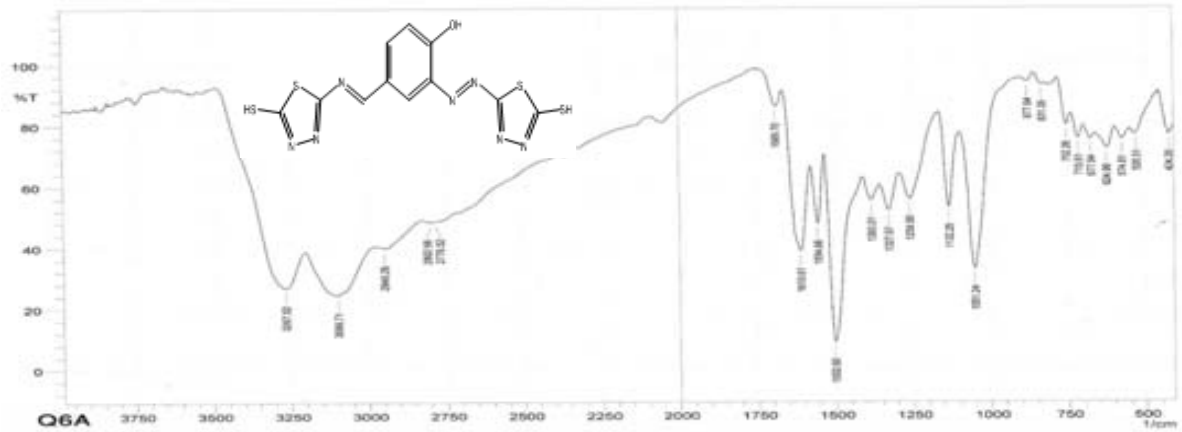

Fig. 8. FTIR spectrum of compound $5 b$ 


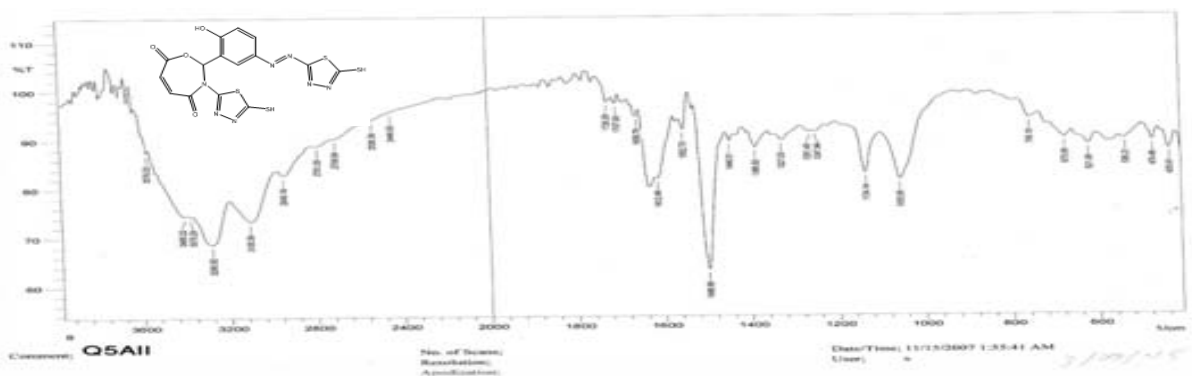

Fig. 9. FTIR spectrum of compound $6 \mathrm{a}$

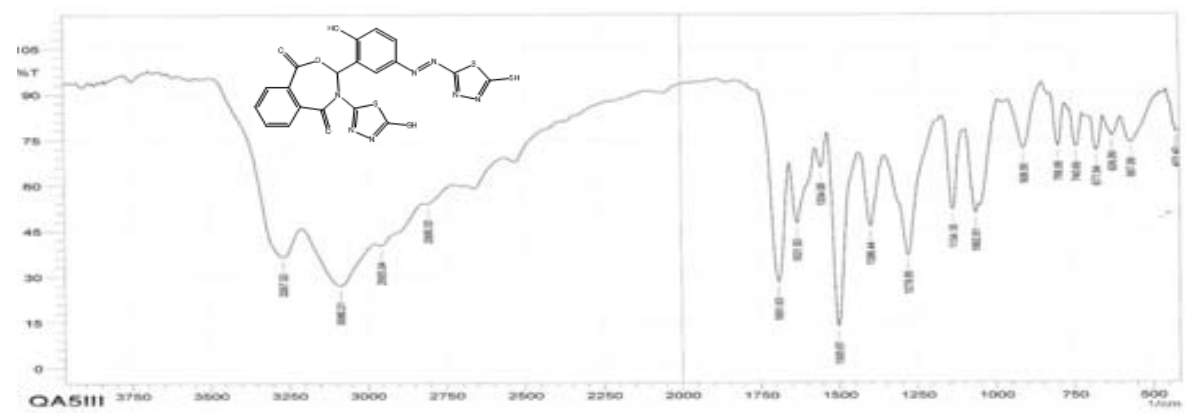

Fig. 10. FTIR spectrum of compound $6 \mathrm{~b}$

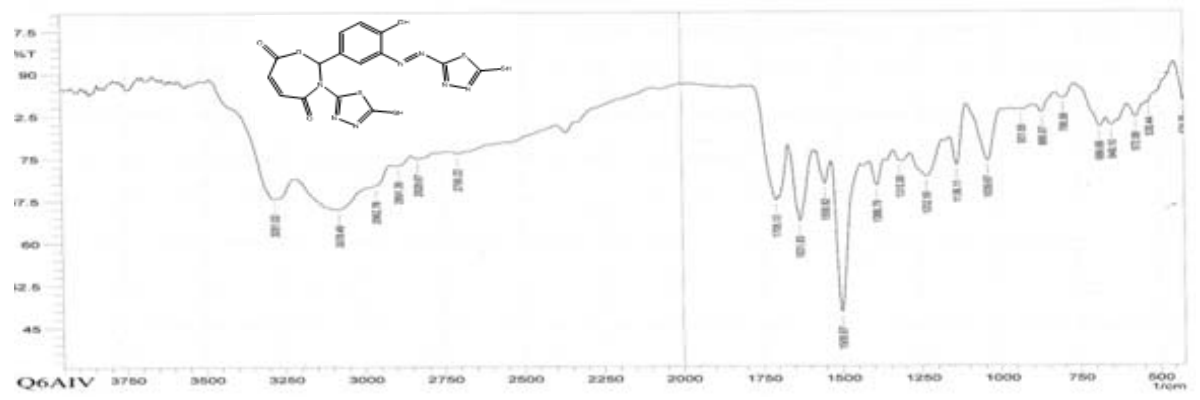

Fig. 11. FTIR spectrum of compound $6 \mathrm{c}$

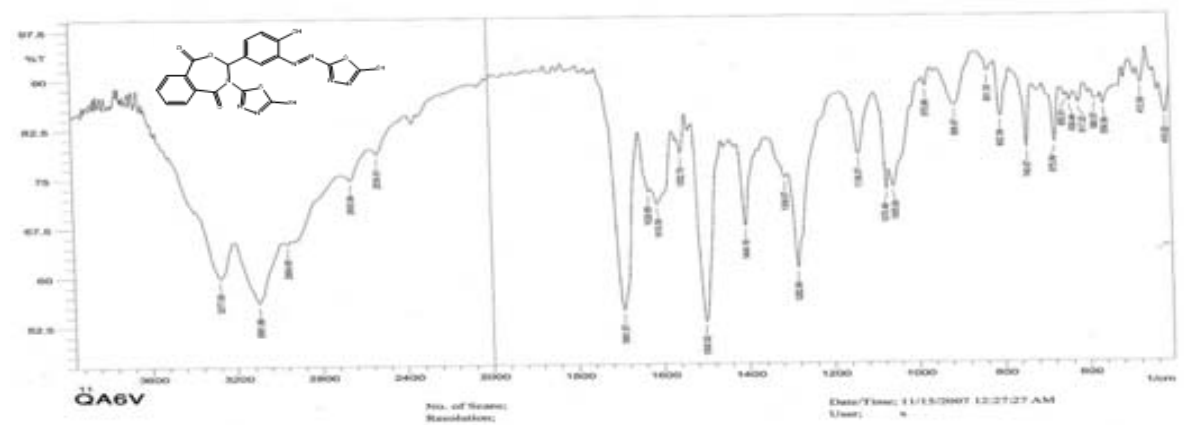

Fig. 12. FTIR spectrum of compound $6 d$ 


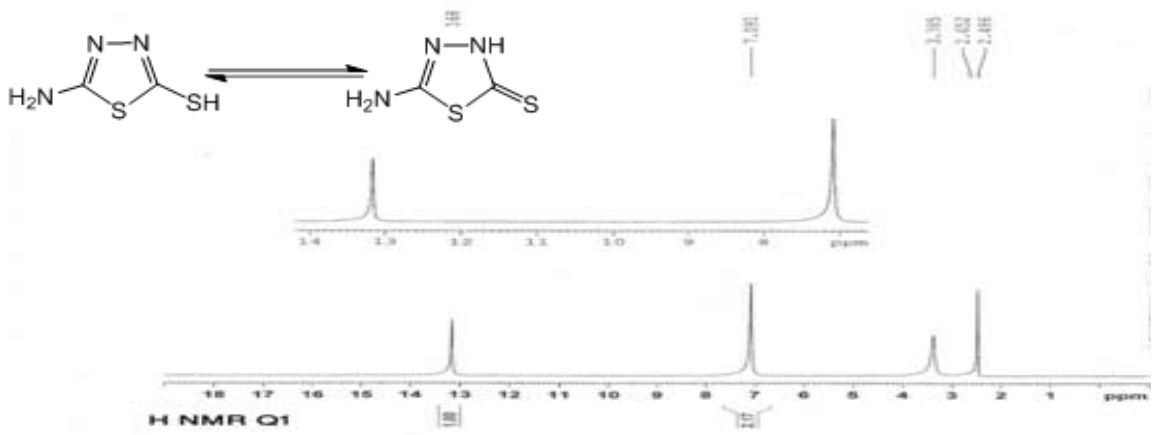

Fig. 13. ${ }^{1}$ HNMR spectrum of compound 1

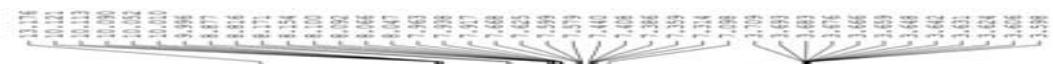
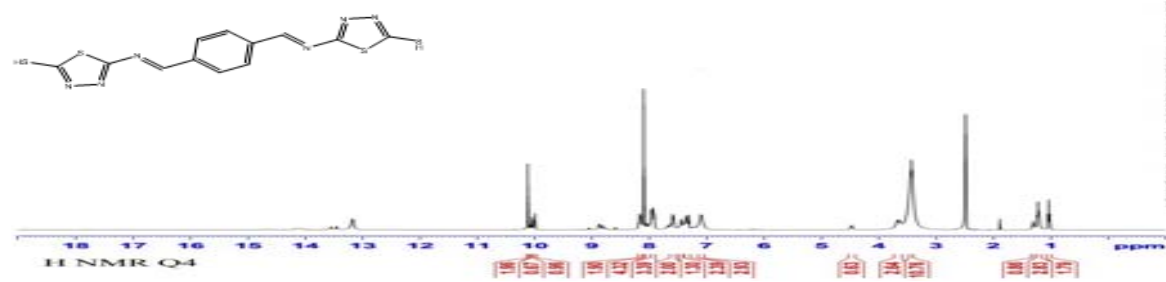

Fig. 14. ${ }^{1}$ HNMR spectrum of compound 2

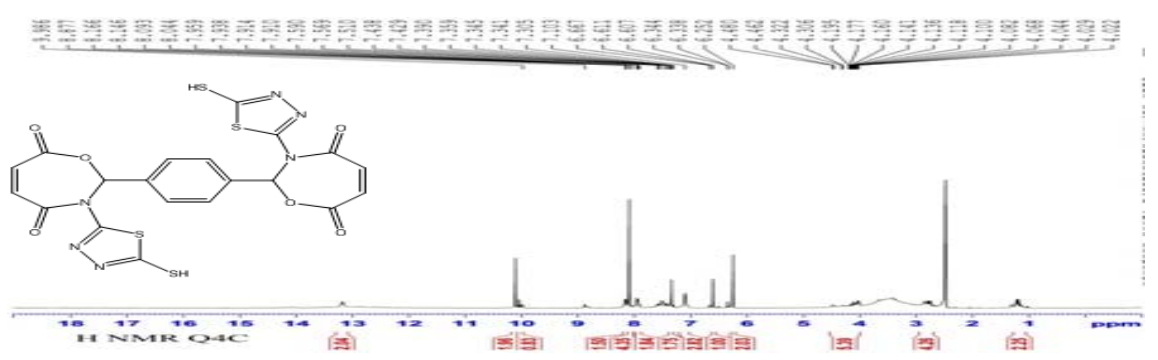

Fig. 15. 'HNMR spectrum of compound 3a

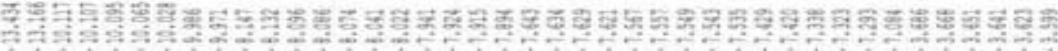

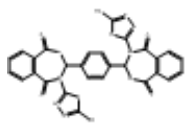

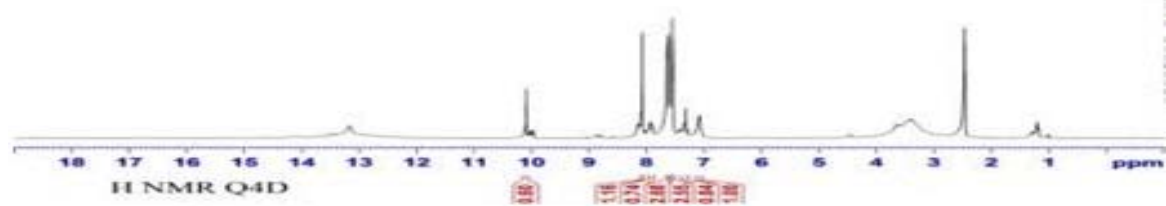

Fig. 16. ${ }^{1}$ HNMR spectrum of compound $3 \mathrm{~b}$ 


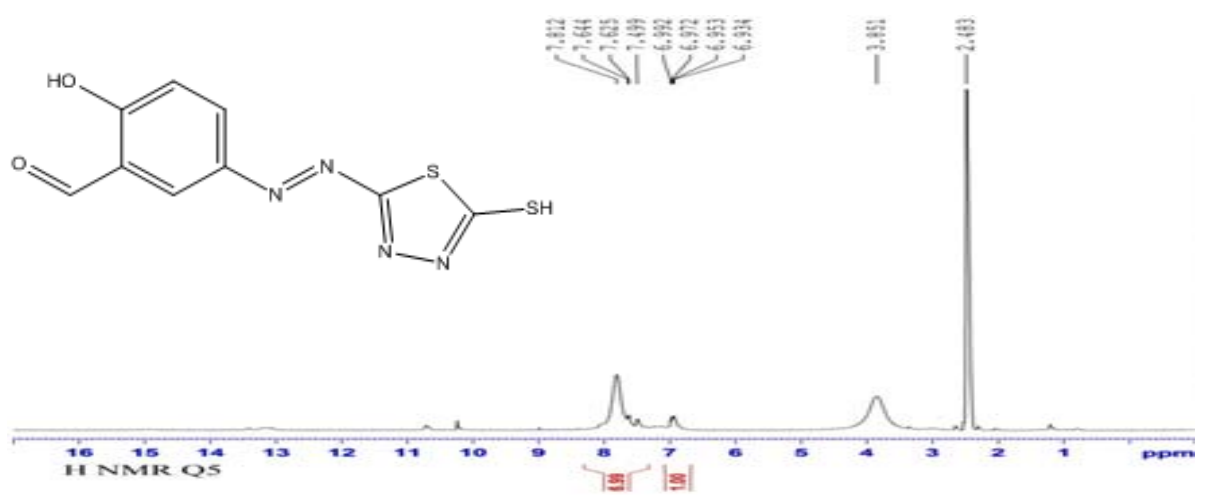

Fig. 17. ${ }^{1}$ HNMR spectrum of compound $4 a$

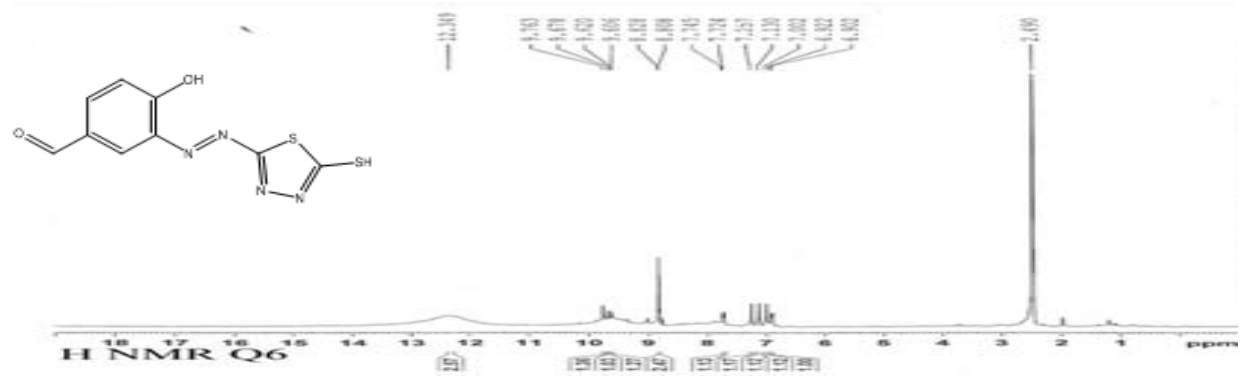

Fig. 18. ${ }^{1}$ HNMR spectrum of compound $4 \mathrm{~b}$

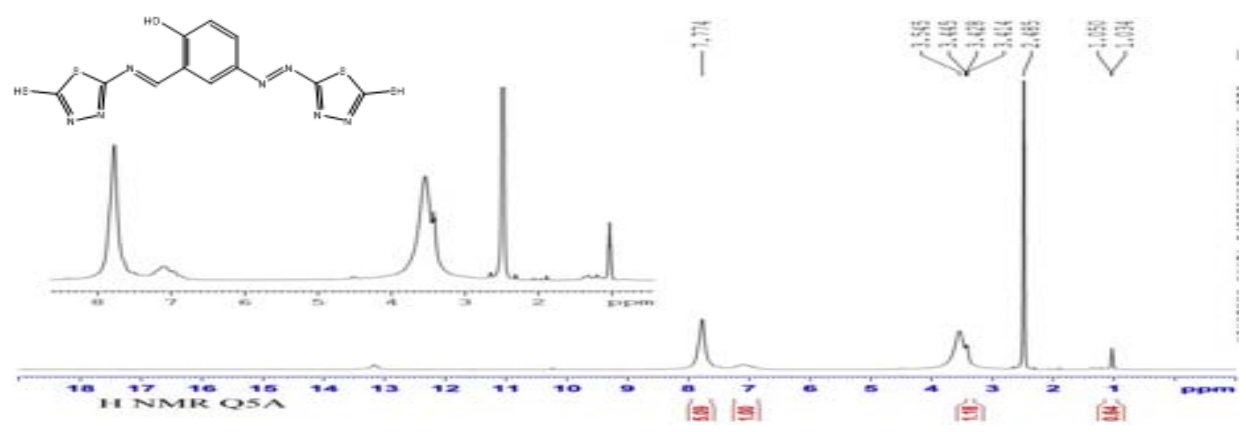

Fig. 19. ${ }^{1} \mathrm{HNMR}$ spectrum of compound $5 \mathrm{a}$

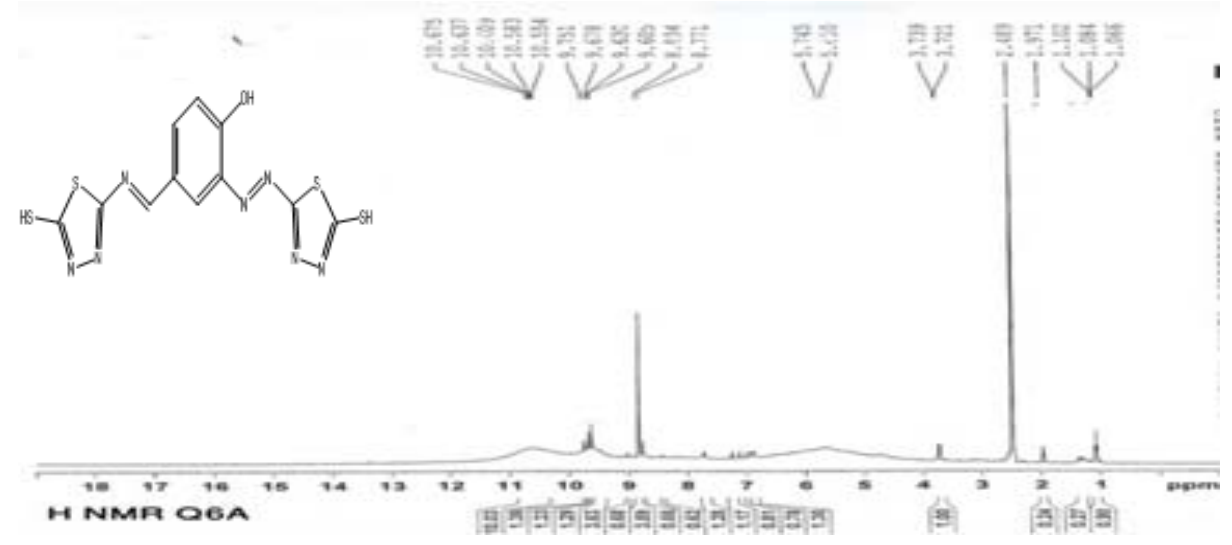

Fig. 20. ${ }^{1}$ HNMR spectrum of compound $5 b$ 


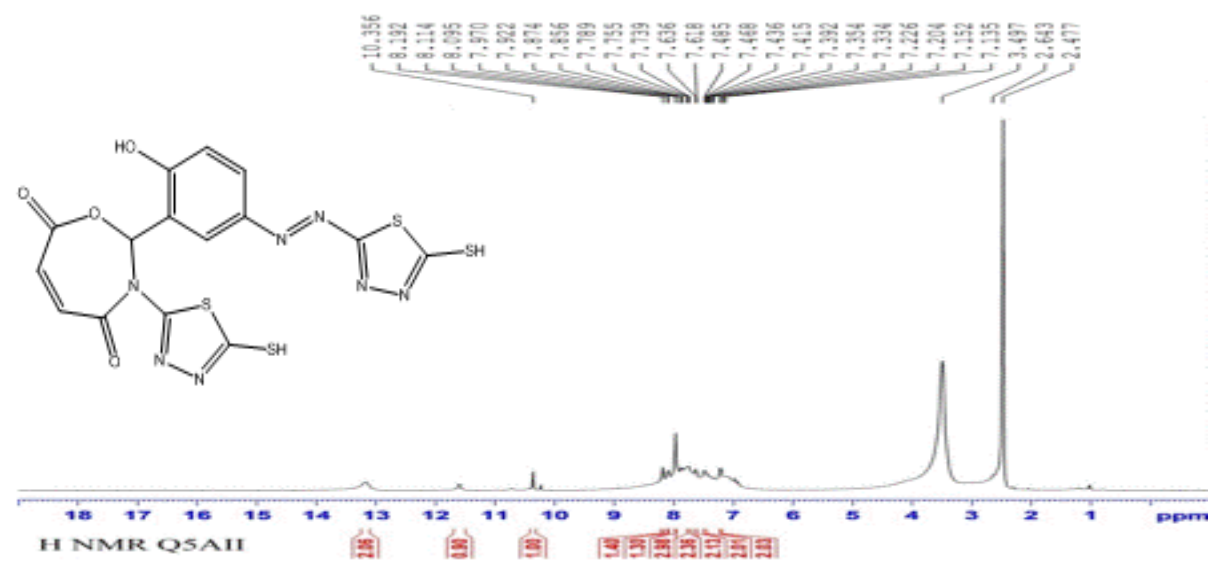

Fig. 21. 1HNMR spectrum of compound 6a
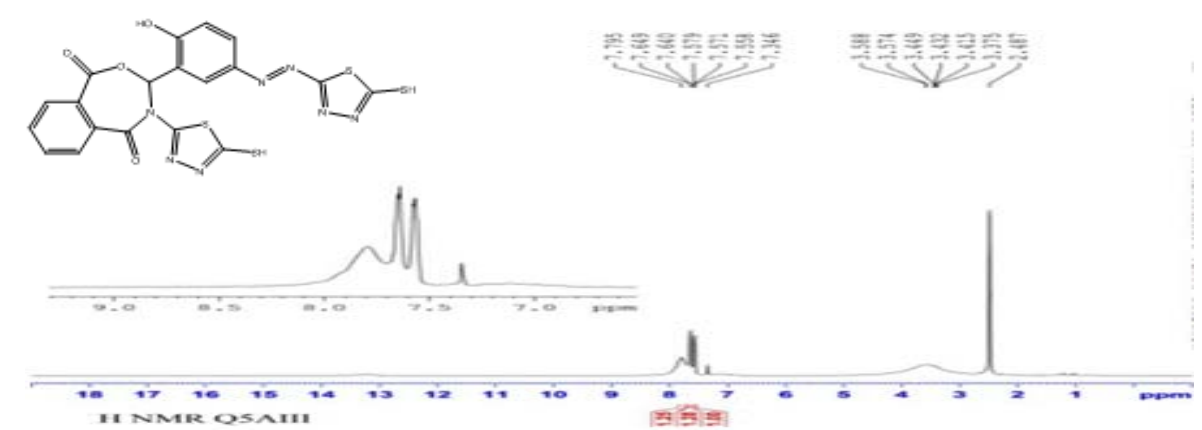

Fig. 22. ${ }^{1}$ HNMR spectrum of compound $6 \mathrm{~b}$

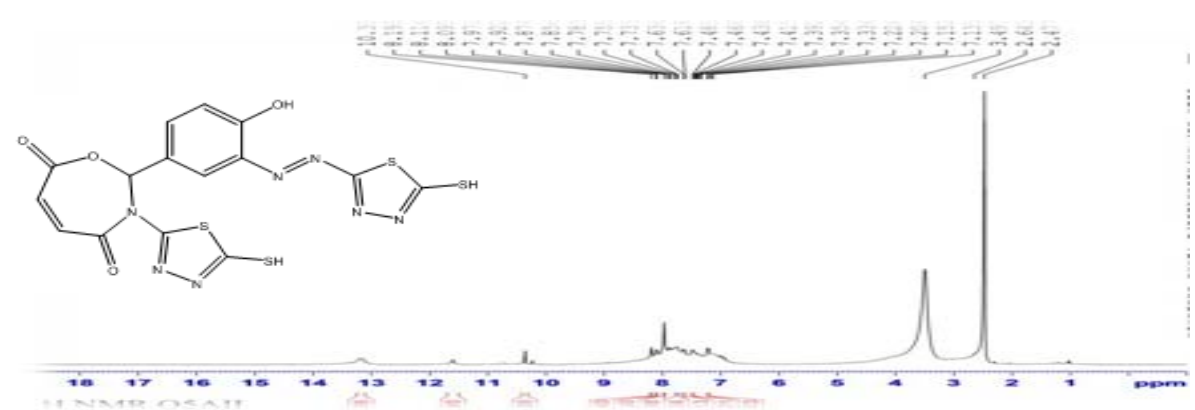

Fig. 23. ${ }^{1}$ HNMR spectrum of compound $6 \mathrm{c}$

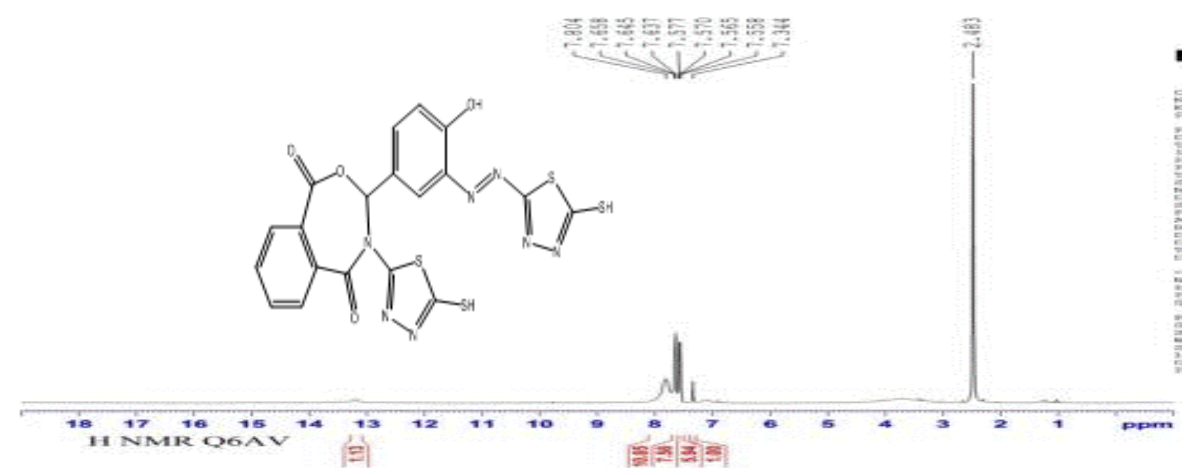

Fig. 24. ${ }^{1} \mathrm{HNMR}$ spectrum of compound $6 \mathrm{~d}$ 


\section{ACKNOWLEDGEMENTS}

We are highly thankful to staff of the central laboratory, University of Kashan, Iran for their significant assistance in ${ }^{1} \mathrm{H}$ NMR and Elemental Analyses of the synthesized compounds.

\section{REFERENCES}

1. S. Jalhan, A. Jidal, A. Gupta and Hemraj, Asian journal of pharmaceutical and clinical Reseach, 2012, 5, 199.

2. M.M. Raj, H.V. Patel, L.M. Raj and N.K. Patel, IJPCBS, 2013 , 3, 814.

3. S. Adhikari, S.B. Bari, A. Samanta, Journal of Applied Chemical Research, 2014, 8, 31.

4. Society of Ecological Chemistry and Engineering, Influence of 1,3,4-thiadiazole derivatives on the biological activity of the selected environmental bacteria, Opole University, 2011 ,18(12), 1691-1692

5. N. Aggarwal, R. Kumar, P. Dureja and J.M. Khurana, Chem Biodrug Des, 2012, 79, 384.

6. M. Amir, A. Kumar, I. Ali and S.A. khan, Indian J. Chem., 2009, 48, 1288.

7. S.H. Joshi and M.K. ThaKer, Indian J. Chem., 2005 44, 410.

8. B. Ahmed and M.d. Yusuf, Indian J. Chem., 2010, 49, 241.

9. D.E. Abdel Rahman and K.O. Mohamed, Der Pharma Chemica, 2014, 6, 323.

10. F. A. Hassan, IJRPC, 2012, 2, 58.

11. A.S. Mayhoub, L. Marler, T.P. Kondratyuk, E.J. Park, J.M. Pezzuto and M. Cushman, Bioorg. Med. Chem., 2012, 20,2427.

12. F. Vergne, P. Bernardelli, E. Lorthiois, N.
Pham, E. Proust, C. Oliveira, A. Mafroud and F. Royer, Bioorg. Med. Chem. Lett., 2004, 14, 4607.

13. M.M. El-Sadek, S.Y. Hassan, H.E. Abdelwahab and G.A. Yacout, Molecules, 2012,17, 8378.

14. E. Oruc, S. Rollas, F. Kandemirli, N. Shavets and A. Dimoglo, J. Med. Chem., 2004,47, 6760.

15. S. Jaiswal and S. Sigh, International Journal of Engineering Research and General Science., 2014, 2, 167.

16. S. Alrammahi and F. A. Alrammahi, International Journal of Advanced Multidisciplinary Research, 2014,1, 38.

17. Y. Hu, C.Y. Li, X.M. Wang, Y.H. Yang and H.L. Zhu, ACS Publications, 2013,27.

18. F. Hajishaabanha and A. Shaabani, RSC adv., 2014, 4, 46844.

19. J.F. Liegeois, F.A. Rogister, J. Bruhwyler, J. Damas, T.P. Nguyen, M.O. Inarejos, E.M. Chleide, M.G. Mercier and J.E. Delarge, J. Med. Chem., 1994,37, 519.

20. Q.A. Acton, Azo Compounds: Advances in Research and Application, Scholarly Paper Edition, Atlanta, p.42 (2011).

21. N.A. Salih, Turk J. Chem., 2008, 32, 229-235 